УДК $007: 304: 001$

\title{
МАНІПУЛЯЦІЯ У ФОТОЖУРНАЛІСТИЦІ ПІД ЧАС ІНФОРМАЦІЙНОЇ ВІЙНИ
}

\author{
Ярослав Табінський \\ Львівський національний університет імені Івана Франка \\ вул. Ген. Чупринки, 49, 79044, Львів, Україна \\ e-mail:tabinskyi@gmail.com \\ https://orcid.org/0000-0002-5122-4253
}

Описано поняття маніпуляції та їі місце у сучасній фотожурналістиці. Охарактеризовано приклади маніпулятивної пропаганди під час інформаційної війни. 3’ясовано принципи ілюстрування фейкових матеріалів, які створюють пропагандивні редакції. Визначено умови та способи протидії маніпулятивним технологіям у фотожурналістиці.

Ключові слова: маніпуляція у фотожурналістиці, фейки, інформаційна війна, «Міна Муравського», маніпулятивна пропаганда.

Медіадослідження, які стосуються маніпуляції, є особливо актуальними в час інформаційної, психологічної, економічної та військової агресії Російської Федерації проти України. У сучасному медіапросторі реципієнт сприймає візуальну інформацію, якою максимально наповнені не лише друковані шпальти, але й інформаційні агентства, веб-портали, а особливо соціальні мережі, які дуже часто виконують маніпулятивну функцію. Насамперед це вплив на емоції, внутрішній духовний та моральний стан людини задля досягнення конкретної мети - переважно розчарування, недовіри, сумніву та навіть страху. Завдяки вдалим образам, символіці та деталям, які найкраще передає фотографія, медіа й впливають на громадськість, формують суспільну думку, створюють певні візуальні шаблони, які використовують для пропаганди.

Мета дослідження зумовлена потребою наукового осмислення сучасних маніпулятивних технологій та полягає у з'ясуванні особливостей маніпуляції у фотожурналістиці в умовах інформаційної війни.

Серед завдань, які необхідно виконати для досягнення мети, - визначення поняття та основних характеристик маніпуляції в медіа, виявлення та аналіз випадків маніпулятивної пропаганди, якої досягають за допомогою впливу фотоілюстрації, окреслення основних способів протидії маніпуляції у фотожурналістиці.

Для окреслення теоретичної складової дослідження використано праці українських науковців Василя Лизанчука, Юрія Шаповала, польського дослідника зобра-

(С) Табінський Я., 2019

Наукове рецензування та рекомендація до друку - проф. Лизанчук В. В. 
жальних медіа Казімєжа Вольного-Зможинського, американського теоретика Кеннета Кобре.

Визначення «маніпуляція», за словниковим тлумаченням, означає дію 3 об'єктами із певними намірами або ж цілями. 3 латинської мови слово manus - рука, manipulus - пригорща, жменя, від manus i ple - наповнювати. У переносному значенні в більшості випадків маніпуляцію трактують як метод чи спосіб впливу на людей або ж управління ними.

Поняття маніпулятивної пропаганди розглядає професор Василь Лизанчук у своєму підручнику «Інформаційна безпека України: теорія і практика». Автор з'ясовує, що маніпуляція - це вид духовного, психологічного впливу, який потребує значної майстерності і знань. Переважно мішенню дій маніпулятора є дух, психічні структури людської особистості. Ідеологічна машина використовує особливі формати маніпулятивної пропаганди такі як метод «гнилого оселедця», тобто медіа підбирають брехливе звинувачення і спрямовують на те, щоб викликати широке публічне обговорення [1,592].

Часто, задля досягнення особливого впливу на реципієнта, ЗМІ використовують фото для ілюстрування матеріалів, що стосуються суспільно значущих подій, зовнішньої та внутрішньої політики, життя представників влади, шоу-бізнесу тощо.

У 20-их роках XX століття маніпулювання фотографією було не лише стандартною процедурою, але й сферою мистецтва. У своєму виданні «Прес-фотографія. 3 об'єктивом за кулісами надзвичайних подій» професор Сан-Франциського університету, дослідник фотожурналістики Кеннет Кобре характеризує зображальну маніпуляцію, яка розпочалась саме з розвитком друкованих медіа. Сучасні редактори шукають нові способи зацікавлення читачів і підживлюють їх увагу, маніпулюючи фотографіями на екранах комп’ютерів, так само охоче, як їх попередники, що використовували ножиці і клей, 90 років тому [2, 390]. Американський науковець описує випадки маніпуляції фотографіями у дуже авторитетних виданнях: Time, Newsweek, New York Times, National Enquirer, National Geographic та інших.

Дослідник фотожурналістики професор Юрій Шаповал зазначає, що фотографія має велику сила переконання, яка полягає в тому, що глядач вірить фотографії як документальному зображенню. Елементи зображальності фотожурналістики зумовлюють нові якості фотографії, зокрема «ефект присутності» та історичну цінність. Ще однією особливістю є вплив на свідомість завдяки зв’язку між відчуттями (зором людини) та почуттями (емоції, які виникають через сигнали мозку) [3, 81].

На думку польського теоретика зображальних медіа Казімєжа Вольного-Зможинського, фотографії, які є відображенням реальності, зберігають не лише пам'ять про навколишній світ, але й допомагають його бачити та краще розуміти. Кожне зображальне повідомлення швидше доходить до одержувача, який без сумніву вірить в щось, що йому показують, а не лише розповідають про щось. Малюнок був однією з найстаріших форм передачі новин. 3 давніх часів заміняв слово, і чим більше містив значень і символів, тим більше впливав на уяву одержувача $[4,31]$.

Небезпечним явищем є маніпуляція фотозображенням задля досягнення пропаганди. Щоправда, в цьому випадку завжди потрібно відмежовувати постановку та реальність - зрежисовані сцени та документальне свідчення подій, що відбуваються особливо в місцях воєнних конфліктів. У 2016 році неприємний випадок навколо фотоілюстрацій зі сходу України серйозно змінив ставлення світових медіа до 
українських журналістів. Було порушено межу маніпуляції зображенням. Тоді українські фотожурналісти оскаржили спробу радника міністра оборони видати пропаганду за документальне фото із зони воєнних дій. Це явище журналісти та дослідники зображальних медіа з того часу називають «міна Муравського».

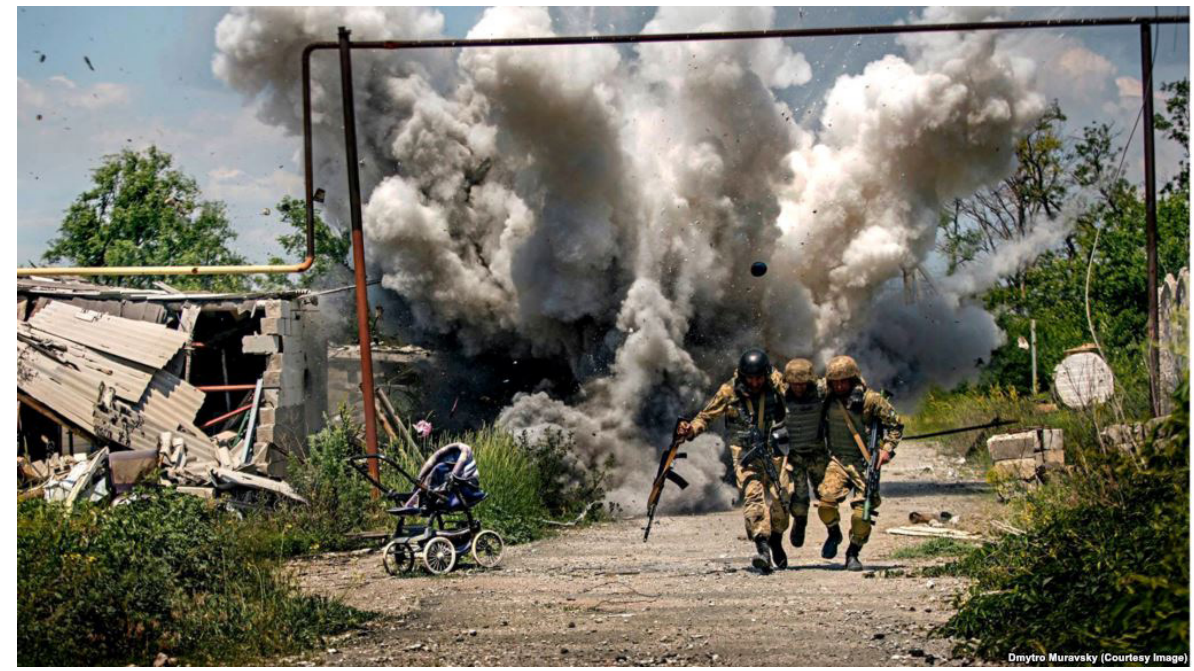

«Вибух... Двоє українських бійиів несуть третього на плечах. Позаду - стовп диму, зліва - дитячий візочок. Ще лівіше - руїни незакінченої війни...» [5]. 4 червня 2016 року Дмитро Муравський, радник міністра оборони, бізнесмен та волонтер, публікує в своєму Фейсбуці фото трьох бійців, які біжать на тлі диму від вибуху. Це зображення Дмитра Муравського «облетіло» світову мережу миттєво. Головний редактор видання «Цензор.нет» Юрій Бутусов зазначив, що цей знімок необхідно зробити знаменитим як еталон військової фотожурналістики, адже в цьому кадрі: біль, страх, ненависть до ворога, жаль до зруйнованого миру... Фото справді вдалось зробити знаменитим. 14 тисяч вподобань (лайків) та 6 тисяч поширень - так розтиражували картину з фронту. Світлину опублікували міжнародні видання, поширили в офіційних сторінках авторитетні політики Європи та США [6]. Але згодом Україна отримала не підтримку, співчуття чи розраду щодо інформації з фронту, а протилежне - відчай та недовіру до засобів масової інформації.

Фотокореспонденти, які по-справжньому працюють на передовій, а деякі з них ледве залишились живими після Іловайського котла, не змогли пропустити таку постановку, яка протидіс обличчю української журналістики, принципам правдивості та об'єктивності. Близько 20 авторитетних фотожурналістів, які висвітлюють події на сході України, звернулись із заявою щодо професійного інциденту. Деякі тези із заяви-звернення: «На жаль, виникла небезпечна ситуація для української фотографії в цілому і журналістики зокрема. По-перше, це новий стимул для РФ зайвий раз розповісти про те, що українці імітують військові дії. По-друге, пильні авторитетні 3MI вже порівнюють ці фото зі стилем подачі інформації Lifenews. По-третє, історія з цими фото може призвести до того, що українське суспільство та авторитетні закордонні медіа частково втратять довіру до української журналістики та фотожур- 
налістики. Наголошуємо, що єдине, в чому ми зараз виграємо у конфлікті з РФ - це безкомпромісна та правдива подача інформації із зони ведення бойових дій» [7].

За чіткими професійними критеріями Макс Левін, Єфрем Лукацький, Сергій Лойко, Олександр Глядєлов та інші вияснили, що ніякого артобстрілу в Широкіному на той момент не було, а підрив був дистанційний. Зауважили також характер вибу$\mathrm{xy}-$ насичений дим, розліт уламків, неприродна поведінка військових. Щоправда, у міністерстві зазначили, що фото в жодному разі не $€$ постановкою.

В інтерв’ю для Hromadske.ua фотокореспондент Олександр Глядєлов зазначив: «Я належу до тих, хто переконаний, що без правди - нікуди. Основна проблема в тому, що немає розуміння на державному рівні, наскільки правда важлива. Не можна естетизувати війну, це один з найгірших проявів існування на нашій планеті. Має 3’явитися розуміння в Адміністрації президента, що треба міняти ставлення до того, як все це показується» [5].

Автор фото Дмитро Муравський, керівник інформаційно-координаційного центру української армії, також був радником міністра оборони, волонтером. Після скандалу навколо відомого фото він захищав власну честь та намагався довести, що фото не зрежисоване, постановки не було і все насправді реальне.

Ситуація принесла загрозу для репутації українських ЗМI. Виникла проблема довіри до України, адже створювати постановки та маніпуляції там, де насправді відбувається захист національних інтересів, дуже недоречно. Автора звільнили 3 Міністерства оборони, проте негативні наслідки тривають і донині, а явище постановки в українській журналістиці тепер називають «міною Муравського». Чому саме міною? Тому що ця зброя може зірватися в найбільш неочікуваний момент та нашкодити найбільше. Такою інфомраційною «міною» й стала фотографія Дмитра Муравського в 2016 році.

Після рішення Міністерства оборони щодо звільнення Дмитра Муравського з посади радника міністра, журналіст Мустафа Найєм прокоментував цю складну ситуацію: «Питання не в тому чи дозволено, чи заборонено знімати постановочні фото, чи ефективно це, чи ні. Такий жанр існує і очевидно спрацьовує. Особливо в рекламних постерах або в сюжетах Russia Today. Проблема в іншому - називати конкретні постановочні кадри документальними - це приниження і обезцінення роботи тисяч інших фотокореспондентів, які ризикують своїм життям заради відтворення реальності» [6].

Українські журналісти в умовах інформаційної агресії з боку Російської Федерації у жодному разі не можуть допускати порушення основних стандартів та професійних правил задля видовищності картинки. Коли йдеться про інформаційну безпеку, важливо розуміти, що Росія через свої агресивні дії не відмовиться від спроб контролю над інформаційним простором, а через нього - над цінностями, настроями та поведінкою жителів підконтрольних територій.

На думку професора Василя Лизанчука, грунтовний аналіз діяльності 3МІ в Україні дає підставу стверджувати, що всі принципи журналістики повинні грунтуватися на засадах україноцентризму, тобто україноцентризм має виконувати роль інтегрувального принципу формування журналістського професіоналізму і функціонування 3МІ [8].

3 цього приводу британський фотожурналіст та засновник Оксфордського фотофестивалю Робін Лоранс вважає, що всі майстри медійних маніпуляцій відчувають силу фотографій і використовують їі, щоб, наприклад, виставити політиків в 
певному ракурсі. Іноді, щоб отримати на виборах більше голосів, вони готові зайти надто далеко. Фотографія є свідченням історії, так як колись був живопис. Ми віримо фоторепортерам, як художникам. «Проблема маніпуляцій в тому, що вона підриває авторитет фотожурналістики. Іноді, повернувши камеру на десять градусів, ми можемо отримати зовсім іншу історію. Завдання фотожурналіста - документувати те, що відбувається, а не інтерпретувати його» [9].

Один з найвідоміших українських фотокореспондентів Єфрем Лукацький в інтерв’ю для порталу Ахios розповів про умови праці фотожурналістів 3 огляду на морально-психологічні аспекти професійної діяльності: «Бували моменти, коли поряд зі мною були зруйновані приміщення, з яких долинали крики про допомогу. Та все, що я міг зробити, - сфотографувати їх. Але чи може фото зупинити кровопролиття? Це питання, яке лишатиметься без відповіді завжди. Зусилля - це не запорука успіху. Фотожурналісту потрібно бути в правильному місці в правильний час» [10].

Команда порталу StopFake працює над перевіркою фактів з березня 2014 року. Саме після трагічних подій на Майдані в Києві, особливо після анексії Криму та початку бойових дій на Донбасі, розпочалась маніпулятивна пропаганда не тільки на окуповані території, але «рупор агресора» максимально спрацював і для Європи, адже трансляції з фейковими новинами поширювали майже на всіх мовах Свропейського союзу. Такого інформаційного тиску ніхто не очікував, а держава ніколи не створювала бар'єрів недовіри, а тим паче не було розроблено концепції інформаційної безпеки та протидії ворожій пропаганді, особливо в інших країнах.

Журналісти, редактори, програмісти, перекладачі сайту StopFake визначають та перевіряють неправдивість фактів кремлівської пропаганди, які щодня з'являються в медійному просторі. Протидіяти такому явищу складно, проте спроби активістів не $\epsilon$ марними. Відомо, що на підсвідомість людини найперше впливає зображення, а тоді вже звук чи прочитаний текст. Саме за допомогою зображальної маніпулятивної пропаганди твориться потрібна картинка, з якої й розпочинається новина. Так для прикладу найяскравішим випадком штучно створених пропагандистських новин $€$ фото маленького хлопчика з Донбасу, який в образі сироти розшукує своїх батьків на тлі зруйнованого українського села. Інформацію подають кремлівські медіа наче «что мальчик ищет свою мать среди развалин разбомбленного ВСУ дома». Лише завдяки зображенню дитини, що суперечить будь-яким нормам журналістської етики, та тексту про розбомблену домівку українськими військовими, пропагандисти отримали емоцію. Саме це почуття, яке розглядають науковці-теоретики, допомагає реципієнтові повірити у зображення, адже фото - документальне. Жаль, біль, розпач, але й ненависть до тих, хто завдав дитині цих жахіть - це перше, що на підсвідомому психологічному рівні відчуває глядач. А далі текст: «После очередного обстрела со стороны украинских освободителей»... Згодом медіаексперти з'ясували, що фотографія - це кадр з відеокліпу «Ангел. Песня о детях Донбасса», в якому діти шукають батьків серед руїн. Насправді батьки хлопчика живі та здорові, сім'я проживає в селі Нікішиному, яке перебуває під контролем російсько-окупаційних військ. Щоправда фотоінформація отримала десятки тисяч репостів, а особливо перепублікацій з антиукраїнським підтекстом у світових медіа. 4 жовтня 2017 року цей пост поширили близько 2000 користувачів у Швеції [11]. 
У мережі дуже багато зображень, які використовують як інструмент пропагади. Це підриває довіру суспільства до журналістів та редакцій засобів масової інформації, але працює на користь антиукраїнських сил.

Під час візиту віце-президента Джо Байдена в Україну в 2015 році в соціальних мережах та проросійських інформаційних сайтах публікували фото, на якому тисячі людей стоять на колінах на вулиці Грушевського. Підписи до фотоілюстрації абсурдні та принизливі: «киевляне, которые «просят Байдена «спасти» их от Яценюка». Насправді фото зроблене під час поминальних заходів 18 січня в День пам'яті Героїв Революції Гідності [12].

Неодноразово пропагандистські медіа використовують не лише помилкові чи завідома неактуальні зображення, але й застосовують технологію ілюстративного монтажу за допомогою спеціальних програм, технічних редакторів тощо. Саме таким способом створюють фотомонтажі, на яких додають потрібні деталі для особливого інформаційного навантаження. У російських соцмережах стало популярне фото, на якому зображено занурення в ополонку чоловіка під час свята Водохреща. Заголовок новини надто провокативний: «Полк «Азов» окунулся в прорубь в виде свастики». Ополонка на змонтованому фото - у вигляді свастики, а в оригіналі хрест. Крім цього світлину зроблено в російській Тулі ще в 2014 році [13].

Ще одне фейкове фото підтверджує маніпулятивну пропаганду в проросійських медіа. У соціальних мережах з хештегами: \#Украина_фашитская, \#Хунта, \#Каратели, \#Гражданская война поширюють зображення з підписом «Марш УПА в Краматорске». На фото діти тримають банер із портретами Шухевича, Бандери і Гітлера. Нижче підпис: «Бог і Україна понад усе!». В Краматорську дійсно відбувались заходи до річниці створення УПА, щоправда фото зроблене 14 жовтня у Львові і замість Гітлера - портрет Коновальця. Пропагандисти вміло здійснили монтаж та ретуш і максимально поширили зображення в мережі [14].

Маніпуляцію використовують також і в географічному вимірі, коли «героями Донбасса» стають мешканці ізраїльських міст, які потерпають від ракетного обстрілу терористів з міста Газа. Російські ЗМІ видають фейкові новини, в яких «картинка» впливає на емоції найбільше, адже на фото діти, яких своїми тілами прикривають перехожі в Донецьку [15].

Український журналіст, медіаконсультант Олександр Піддубний провів дослідження «Біженці, яких нема, або маніпуляції з одним знімком» [16]. Тема, яку рапортують кремлівські медіа, стосується українських біженців, яким начебто Росія створює умови для комфортного життя на території Ростовської області. Жодних доказів цього Росія не має, натомість головною ілюстрацією для дискредитації України стала фотографія Андрія Петрова з агентства Associated Press, на якій зображена дівчинка крізь віконну шибу автобуса. Її українська влада евакуювала зі Слов’янська ще 6 червня 2014 року. Вперше фото з'явилося на сторінці видання Los Angeles Times 10 червня з повідомленням про розпорядження Петра Порошенка про евакуацію дітей. Далі фото підхоплює сербський проросійський сайт Politika, а вже потім запрацювали кремлівські пропагандисти. Лише один новинний портал Pravda.ru цією світлиною ілюструє більше п’яти матеріалів з такими заголовками: «B Новороссии гуманитарная катастрофа», «Новоросов ждут фильтрационные лагеря», «Дещица требует у Лаврова, чтобы Россия вернула детей-сирот, вывезенных из-под бомбежек», «Украинские военные обстреляли автобус с детьми на границе с Россией». 
Пропагандисти готують чимало матеріалів англійською мовою, зокрема: «At least 500 Ukrainian refugees flee to Crimea daily» («Щонайменше 500 українських біженців щодня прибувають до Криму»). Не залишається осторонь конфлікту «русское православие», адже на російському християнському порталі Pravoslavie.ru вищезгадане фото української дівчинки в автобусі ілюструє текстівку з заголовком: «Митрополит Ростовский Меркурий: церковь делает все возможное, чтобы помочь беженцам». У тривожній новині російських церковників йдеться про надзвичайну ситуацію 3 «беженцами с Украины» в Ростовській області. Звісно, церква робить все можливе, щоб допомогти людям «избавиться от страха и оцепенения». Очевидно, фото маленької дівчинки, яку евакуювала українська влада подалі від проросійських терористів, мало проілюструвати цей «страх».

Дослідник Олександр Піддубний проводить паралелі та звертає увагу, що сайт Pravoslavie.ru також доступний і сербською мовою. А, як видно з початку дослідження, саме сербський сайт Politika використав фото дівчинки як антиукраїнський пропагандистський інструмент.

Автор переконаний, що з цієї історії можемо чітко виокремити інформаційні стовпи, на які опирається російська пропаганда. Насамперед це сербські прокремлівські медіа, які постійно описують підтримку донецьких ополченців та участь бойовиків із Сербії. Не обійшлось без підтримки російської православної церкви 3 усією агентурною мережею в Україні. Щоправда, медіадослідник не має відповіді на питання - чим завинила бідна дівчинка на фото, яку так жорстоко використали, відправляючи в кращому випадку в Крим, а в гіршому - у фільтраційний табір. Олександр Піддубний зазначає, що готовий надати докази в суді, а саме знімки з екранів та публікацій, а батьки дівчинки можуть спокійно позиватися до Європейського суду з прав людини проти антиукраїнських пропагандистів щодо захисту честі і гідності, а особливо використання фото їхньої дитини з корисливою політичною метою [16].

Використання фотографії для досягнення маніпулятивної пропаганди відбулось в час президентської виборчої кампанії навесні 2019 року. Одним з яскравих прикладів стало фото Леоніда Шевчука, фоторепортера агентства УНІАН, який висвітлював мітинг за участі Президента України Петра Порошенка в Житомирі. Як тільки фото з'явились в мережі, російські пропагандистські медіа максимально поширили скадроване (обрізане) фото для ілюстрації новин із заголовками: «Побег Порошенко с митинга в Житомире». Ця світлина стала основою для маніпуляцій з інформаційним приводом «президент убегает из своего предвыборного митинга, после того, как местные жители довольно холодно его встретили» [17].

На фото чітко видно як Порошенко переступає широким кроком калюжу, а за ним услід поспішає охорона. Перспективи для руху об’єкта на фото немає, тому все, що залишилось поза цим кадром, для реципієнта російських медіа стає невідомим. Russia Today проілюструвала інформаційний матеріал з посиланням на портал Strana.UA [18]. Тисячі перепостів новини з фотографією президента-втікача, десятки тисяч вподобань у соцмережах, а в коментарях суцільні глузування, бруд, ненависть, інформаційна агресія та ворожнеча. Ефект від фото очевидний: інформаційним пропагандистам вдалось вразити ціль якнайточніше. Щоправда, відповідь прес-секретаря Президента України була миттєвою. Святослав Цеголко у своєму Фейсбуці завантажив серію оригінальних фото та повідомив: «Класичний фейк, коли фото підрізають. Сподіваюся, у тих, хто його поширив, вистачить сміливості подати спро- 

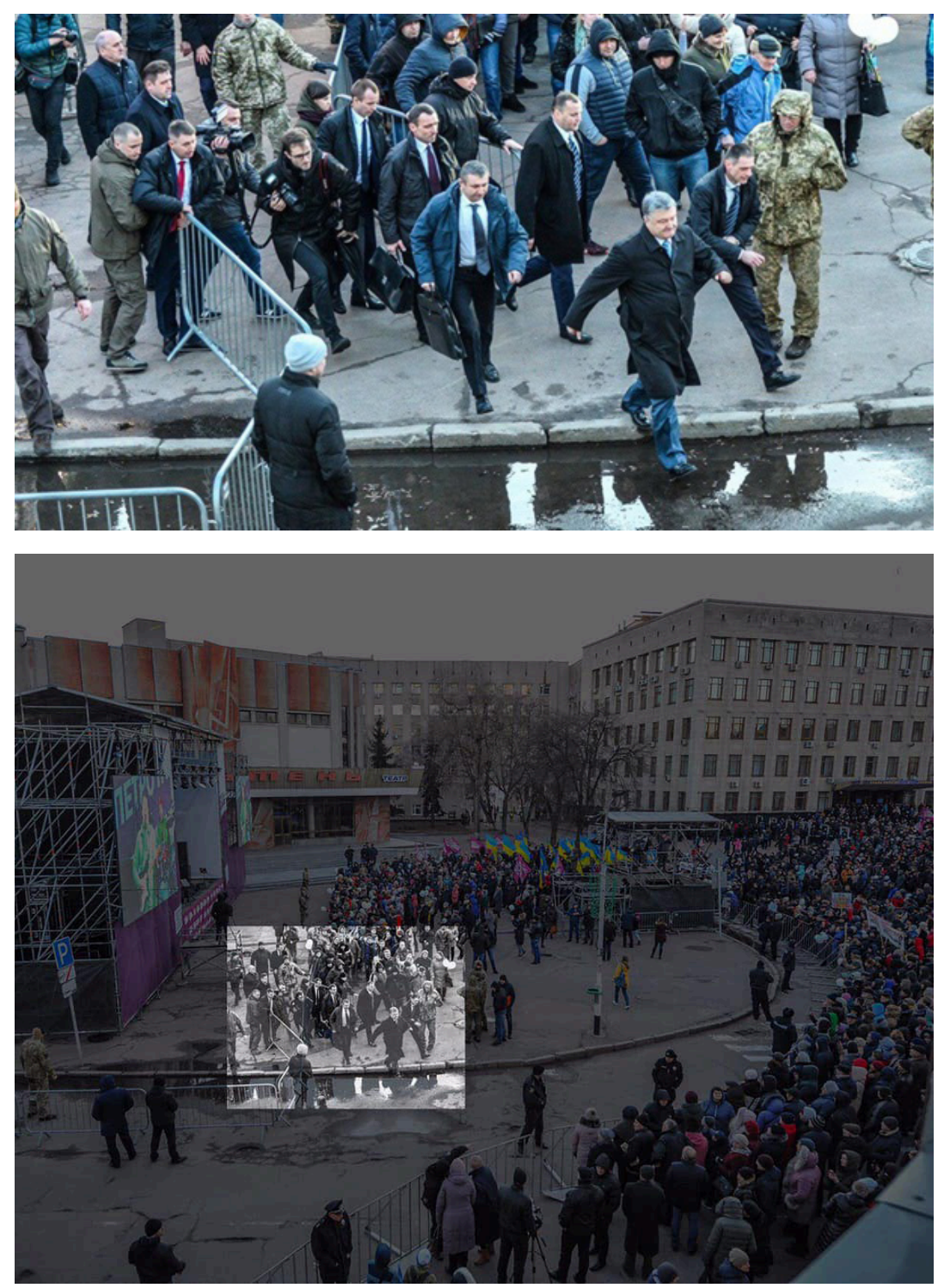

стування. Ні сміливості, ні совісті не вистачить лише пропагандистам з РФ та їхнім посіпакам» [19].

Реакція автора фото з мітингу у Житомирі фотокореспондента Леоніда Шевчука стосувалася спростування: «Я - автор фото з Президентом, який йде до народу! Він не втік, не залишає, а переходить до натовпу з тисячі людей, в тому числі опонентів. Кадри зроблені перед мітингом, коли Президент тільки виходить до людей» [20]. Автор під цією публікацією подає також усі фото з події без будь-якої корекції.

Описаний приклад $є$ один із зразків очевидної маніпуляції за допомогою потрібного ракурсу чи звичайного кадрування фотографії. Таку просту, але результа- 
тивну технологію для досягнення інформаційної провокації пропагандистські ЗМІ використовують досить часто.

Зважаючи на описані маніпулятивні технології, українським журналістам необхідно найкраще співпрацювати 3 прес-службами та діяти на випередження, вміло протидіяти схожим технікам завдяки публікаціям з правдивим змістом, а фото та відеоматеріали використовувати як документальне свідчення подій, які відбулися. Серед можливих шляхів вирішення проблеми із загрозою російської пропаганди є створення спеціальних державних інституцій, які б контролювали використання маніпуляцій та створювали контрпропагандистські матеріали з поширенням на світові медіа.

\section{REFERENCES}

1. Лизанчук В. Інформаційна безпека України: теорія і практика: підручник / В. Лизанчук. Львів : ЛНУ ім. Івана Франка, 2017. 728 с.

2. Kobre K. Fotografia prasowa. Z obiektywem za kulisami niezwykłych wydarzeń. / K. Kobre // Polish language edition published by Helion S.A. 2011. P. 512.

3. Шаповал Ю. Феномен журналістики: проблеми теорії / Ю. Шаповал. Рівне : РВП «Poca», 2005. $248 \mathrm{c}$.

4. Wolny-Zmorzyński K. Fotograficzne gatunki dziennikarskie / Kazimierz Wolny-Zmorzyński. Warszawa. 2007. S. 136.

5. Тохмахчі А. «Міна інформаційної дії». Чим шкодять Україні постановочні фото 3 передової [Електронний ресурс] / А. Тохмахчі // Hromadske.ua. 2016. Режим доступу до джерела: https://goo.gl/JQVz4d

6. Сєтєвой П. Міна Муравського: в Україні розгорівся один з найгучніших мережевих скандалів [Електронний ресурс] / П. Сєтєвой // Apostrophe.ua. 2016. Режим доступу до джерела: https://goo.gl/6dJvx5

7. Заява українських фотожурналістів щодо ситуації з фотографіями Дмитра Муравського [Електронний ресурс] // LB.ua. 2016. Режим доступу до джерела: https:// goo.gl/ojtkK4

8. Лизанчук В. Україноцентризм - інтегруючий принцип формування журналістського професіоналізму [Електронний ресурс] / В. Лизанчук // Journ.lnu.edu.ua. 2014. Режим доступу до джерела: https://goo.gl/jFkRd9

9. Гоші Т. Робін Лоранс: Головне завдання фотожурналістики зараз - вижити [Електронний ресурс] / Т. Гоші // Birdinflight.com. 2014. Режим доступу до джерела: https://goo.gl/vTQqR7

10. Фарисей А. Інтерв’ю з фоторепортером Єфремом Лукацьким [Електронний реcypc] / А. Фарисей // Axios.ua. 2017. Режим доступу до джерела: https:/goo.gl/ uLpaGj

11. Как фотофейк о мальчике из Донбасса «мигрировал» в Швецию [Електронний pecypc] // Stopfake.org. 2015. Режим доступу до джерела: https://goo.gl/m169Zz

12. Фотофейк: киевляне стали на колени перед Байденом [Електронний ресурс] // Stopfake.org. 2015. Режим доступу до джерела: https://goo.gl/gN3U5X

13. Фотофейк: Полк «Азов» окунулся в прорубь в виде свастики [Електронний ресурc] // Stopfake.org. 2015. Режим доступу до джерела: https://goo.gl/bSi9NF

14. Фотофейк: портрет Гитлера на плакате украинских националистов [Електронний pecypc] // Stopfake.org. - 2014. Режим доступу до джерела: https://goo.gl/w6G6Nq 
15. Фотофейк: обстрел в Израиле представили как события в Донецке [Електронний pecypc] // Stopfake.org. - 2015. Режим доступу до джерела: https://goo.gl/a2N2hH

16. Піддубний О. Біженці, яких нема, або маніпуляції з одним знімком [Електронний pecypc] / О. Піддубний // Piddubny.com. 2014. Режим доступу до джерела: https:// goo.gl/uRJdV7

17. В сети появилось фото спешно покидающего митинг в Житомире Порошенко [Електронний pecypc] // Russian.rt.com. 2019. Режим доступу до джерела: https:// goo.gl/mLyp8y

18. Скандальное фото Порошенко. От кого и куда на самом деле бежал президент в Житомире [Електронний ресурс] // Strana.ua. 2019. Режим доступу до джерела: https://goo.gl/KaA2T8

19. Цеголко спростував фейк про «втечу» Порошенка з мітингу у Житомирі [Електронний ресурс] // Ukrinform.ua. 2019. Режим доступу до джерела: https://goo.gl/ $\mathrm{icD} 4 \mathrm{zE}$

20.Шевчук Л. Репортер [Електронний ресурс] / Л. Шевчук // Facebook.com/leoztr. 2019. Режим доступу до джерела: https://goo.gl/vZDLRr

\title{
MANIPULATION IN PHOTOJOURNALISM AT THE TIME OF THE INFORMATION WAR
}

\author{
Yaroslav Tabinskyi \\ Ivan Franko National University of Lviv \\ Gen. Chuprynky street, 49, 79044, Lviv, Ukraine \\ e-mail:tabinskyi@gmail.com \\ https://orcid.org/0000-0002-5122-4253
}

In this article the author compares the manipulative technologies that are very active in the media. The topic is relevant during the Russian aggression on the territory of Ukraine. The concept of manipulation is described, examples of photography in the media are used, where manipulative propaganda is carried out. «Bomb of Muravski» is an important example in Ukrainian photojournalism. This phenomen is associated with the creation of staging photos and the distribution of them as a documentary image. Explored fake news that distributing by Russian media. Propaganda is the basis of their work, and photography is an instrument. The truth is the most important weapon against manipulative propaganda.

Ukrainian journalists should work with press services, publish only true texts, photos, videos. A special role is played by the state in controlling manipulation and creating counterpropaganda. Russia's undeclared war against Ukraine urges an in-depth analysis, to understand functions, methods and forms of propaganda in current conditions. Extremely important to inform citizens of Russia and Europe about what is going on in Ukraine. To sum it up we may say that presence of Russian propaganda in Ukrainian media environment is possible due to certain habits, attitudes and stereotypes about Russia shared by certain part of Ukrainian society. Consequently, politicians and politically managed media are tempted to repeat foreign hostile propaganda and use it for their goals.

Key words: Manipulation in photojournalism, fakes, information warfare, «Bomb of Muravski», manipulative propaganda. 